\title{
KESETARAAN GENDER DALAM POLA ASUH ANAK PEREMPUAN GAYO
}

\author{
Nurbaiti \\ UIN Syarif Hidayatullah Jakarta \\ Email: nurbaiti.dpk@uinjkt.ac.id
}

\begin{abstract}
This study about gender equality in parenting style in Gayo's family. The purpose of this study was to determine the Gayo's parenting style in a gender's perspective. The focus of this study on Gayo's parenting style in education. The method used is a qualitative research method. We collected data by questionnaires, interviews and observations in 11 Gayo's families who lives in Jakarta, Bogor, Depok, Tangerang and Bekasi (Jabodetabek) and we used purposive sampling type. Data validity by snowbowling and data analysis by triangulation. The results proved, Gayo's family is a tribe that applies a patrilineal and pariarchy system, so dominant power is found in men. In many cases, men are more dominant than women. It has an impact on the parenting style to their children, but Gayo's parenting style has a gender's equality in education, it can be seen from the results of this study. This study proved, the Gayo's family provides equal educational opportunities both boys and girls in the form of family parenting, all children are taught how to behave and speak according to Islam and their culture, likewise the family provides opportunities for boys and girls in obtaining formal education.
\end{abstract}

Keywords: Gender equality, parenting Style, children, Gayo, education, 


\begin{abstract}
ABSTRAK
Penelitian ini membahas tentang kesetaraan gender dalam pola asuh anak perempuan pada keluarga Gayo. Tujuan dari penelitian ini untuk mengetahui bentuk pola asuh kesetaraan gender anak perempuan pada suku Gayo . Fokus penelitian pada pola asuh anak dalam hal pendidikan. Metode yang digunakan adalah metode penelitian kualitatif. Pengumpulan data dilakukan dengan menggunakan angket, wawancara dan observasi. Jumlah sample sebanyak 11 keluarga Gayo yang berdomisili di Jakarta, Bogor, Depok, Tangerang dan Bekasi(Jabodetabek) dengan jenis sampling purposive sampling (Sampling bertujuan). Validitas data dilakukan dengan menggunakan snowbowling (bola salju) dan analisis data dilakukan dengan menggunakan triangulsi. Hasil penelitian menunjukkan, suku Gayo merupakan suku yang menerapkan system patrilineal atau kekerabatan ditarik dari garis ayah dan system pariarki atau kekuasaan dominan terdapat pada laki-laki, sehingga dalam banyak hal, laki-laki lebih dominan dibandingkan dengan perepmpuan. Hal ini berdampak pada model pola asuh yang diberikan orang tua kepada anak-anaknya. Namun dalam hal pendidikan, para orang tua Gayo melakukan pola asuh dengan kesetaraan gender, hal ini terlihat dari hasil penelitian yang menunjukkan bahwa suku gayo memberikan kesempatan pendidikan yang sama baik pada anak laki-laki maupun anak perempuan dalam bentuk pola asuh keluarga, semua anak diajarkan bagaimana bersikap dan berbicara sesuai dengan ajaran agama Islam dan budaya mereka, demikian juga keluarga memberikan kesempatan yang sama baik kepada anak laki-laki maupun anak perempuan dalam memperoleh pendidikan formal.
\end{abstract}

Kata kunci : kesetaraan Gender, Pola Asuh, Anak, Suku Gayo, pendidikan,

\title{
Pendahuluan
}

Keluarga memiliki peranan sangat penting dalam pembentukan kepribadian anak. Dalam lingkungan keluargalah anak tumbuh dan berkembang serta meraih kesuksesan. Keluarga seperti dinyatakan oleh Sharma merupakan orang-orang yang biasanya tinggal di rumah yang sama, kecuali bekerja, belajar, dipenjara, dikurung, tinggal di luar negeri, atau urgensi lain yang memaksa anggota keluarga untuk sementara tinggal jauh dari rumah bersama(Sharma, 2013). Oleh karena itu, keluarga yang terdiri dari ayah, ibu dan anak-anaknya merupakan institusi pendidikan primer sebelum anak mendapatkan pendidikan di lembaga lain. Pendidikan yang diperoleh anak dari keluarga dalam bentuk pola asuh.

Pola asuh atau gaya pengasuhan orang tua terhadap anak, akan mempengaruhi banyak hal, terutama pada perilaku dan prestasi akademik anak. Kuppens dan Ceulemans menyatakan bahwa Praktek pengasuhan anak dapat didefinisikan sebagai perilaku spesifik yang dapat diamati secara langsung yang digunakan orang tua untuk mensosialisasikan anak-anak mereka, sehingga pola asuh memainkan peran penting dalam perkembangan anak(Kuppens \& Ceulemans, 2019).

Pengasuhan anak menurut Merlina, tidak hanya meliputi mendidik, menjaga, merawat, serta membimbing anak-anak dalam keluarga, tetapi juga mendidik kesopanan, saling menghormati, disiplin, serta kebersihan dan kesehatan. Dalam hal ini sosialisasi adalah proses seorang individu berinteraksi dengan sesamanya(Merlina, 2010). Sementara Swaroopa mendefinisikan pola asuh sebagai upaya dari orang tua dalam menyiapkan anak menjadi penerima dan memainkan peranan kunci dalam pengembangan dan kesuksesan karir anak(Rani, 2014). 
Dengan demikian dapat disimpulkan, pola asuh dapat menjadi penentu keberhasilan anak. Hal ini disebabkan pola asuh menjadi penentu terbentuknya pembiasaan dalam diri anak dan pembiasaan merupakan upaya praktis dalam pendidikan dan pembinaan anak.

Pembiasaan yang baik, sangat penting dilakukan sejak awal kehidupan anak. Agama Islam sangat mementingkan pendidikan pembiasaan, dengan pembiasaan itulah diharapkan peserta didik mengamalkan ajaran agamanya secara berkelanjutan. Pola asuh yang baik akan membentuk hasil yang baik, baik dalam hal kedisiplinan anak maupun kebiasaan-kebiasaan lainnya, demikian juga sebaliknya.

Pendidikan melalui pembiasaan sesuai dengan teori yang dinyatakan oleh Duschinsky (2012). Duschinsky mendukung teori tabula rasa yang dinyatakan oleh John Lock. Duschinsky menyatakan, menurut teori pendidikan tabula rasa, saat anak dilahirkan, anak tidak tahu apa-apa, anak hanya melakukan segala sesuatu yang bersifat instink saja. Oleh karena itulah Locke menyarankan adanya latihan untuk pendidikan anak, agar bisa membuat yang dia pelajari sebagai kebiasaan yang mudah dan alami, sehingga anak bisa memperbaiki dirinya melalui pembiasaan yang telah dilakukannya(Duschinsky, 2012) .

Pendidikan yang diterima anak melalui pembiasaan dapat diperoleh melalui pola asuh dalam keluarga dan pola asuh antara keluarga satu dengan keluarga lainnya berbeda-beda. Banyak faktor yang dapat mempengaruhi pola asuh. Salah satu faktor yang turut menentukan bentuk pola asuh orang tua terhadap anaknya adalah budaya.

Pengasuhan orang tua terhadap seorang anak dilakukan menurut nilai budaya yang diyakini oleh kedua orang tuanya, seperti dinyatakan oleh Kuppens dan Ceulemans (2018) bahwa budaya memengaruhi praktik membesarkan anak(Kuppens \& Ceulemans, 2019). Hal yang sama juga dinyatakan oleh Nauli, et;al (2019), bahwa Pola asuh yang diterapkan oleh orangtua juga tidak lepas dari pengaruh nilai dalam budaya tertentu terutama budaya lokal tempat menetapnya sebuah keluarga (Nauli et al., 2019). Dengan demikian, jenis gaya pengasuhan yang digunakan oleh orang tua sering ditentukan oleh latar belakang budaya dan pengasuhan mereka sendiri. Proses sosialisasi nilai budaya tersebut dapat dilakukan melalui komunikasi baik secara verbal maupun komunikasi non verbal antara orangtua dan anak, sehingga pola asuh merupakan warisan budaya yang didapatkan dari para orang tua, yang kemudian diperlakukan kepada anak mereka.

Dalam hal gender, budaya sering kali dianggap sebagai hal yang menimbulnya terjadi stereotype dalam masyarakat. Hal ini berarti bahwa salah satu penyebab terjadinya diskriminasi gender dalam masyarakat adalah budaya.

Adanya persepsi berbeda dalam hal gender, menimbulkan pola asuh yang berbeda pada tiap keluarga bahkan pada tiap daerah. Harapan orangtua tentang perkembangan anak berbeda secara nyata menurut budaya. Pola asuh orang tua tidak hanya mencakup bagaimana orangtua memperlakukan anaknya, tetapi juga bagaimana orangtua mendidik, membimbing dan melindungi anak untuk mencapai kedewasaan dengan nilai, norma dan kebudayaan masyarakat. Hal ini juga terjadi pada keluarga Gayo.

Gayo adalah suku bangsa yang mendiami dataran tinggi Gayo. Suku Gayo secara mayoritas terdapat di kabupaten Aceh Tengah, Bener Meriah dan Gayo Lues. Ketiga kabupaten itu yang sering dikenal dengan dataran tinggi Gayo. Masyarakat Gayo saat ini banyak yang sudah menjadi penduduk DKI Jakarta dan sekitarnya, mereka tersebar antara lain di wilayah Jakarta selatan, Jakarta barat, Jakarta timur, 
Jakarta pusat bahkan juga di Bogor, Depok, Tangerang dan Bekasi. Namun demikian sebagian besar dalam memberikan pola asuh terhadap anak, mereka masih memegang teguh budaya dan tradisi yang dimilikinya.

Mereka menganut sistem kekerabatan patrilineal yaitu bersifat kebapaan yang pada prinsipnya, sistem ini merupakan sistem kekerabatan yang menarik garis keturunan ayah atau garis keturunan nenek moyangnya yang laki-laki. Pada system patrilineal biasanya menerapkan faham patriarki.

Patrilineal dan patriarki merupakan dua hal yang memiliki kemiripan, yaitu sama-sama menempatkan laki-laki pada posisi lebih dominan dibandingkan perempuan, namun patrilineal lebih menekankan pada sistem kekerabatan yang ditarik dari pihak laki-laki dan patriarki lebih menekankan pada bentuk kekuasaan ada pada laki-laki. Biasanya keduanya berjalan beriringan, yaitu pada sistem patrilineal juga akan menerapkan faham patriarki. Pada sistem patrilineal, peran laki-laki dan anak laki-laki sangat penting, karena anak laki-laki sebagai penerus keturunan dan gelar kebangsawan. Sedangkan peran perempuan dan anak perempuan dinomorduakan.

Dengan demikian, dalam banyak hal terdapat bias gender antara laki-laki dan perempuan pada pola asuh anak pada keluarga Gayo, namun hal ini tidak terjadi pada saat mereka melakukan pola asuh dalam bidang pendidikan. Dalam hal memperoleh pendidikan, keluarga Gayo memberikan perlakuan yang setara, sehingga baik anak laki-laki maupun anak perempuan mendapatkan kesempatan yang sama. Dalam hal pengasuhan anak dalam keluarga, baik anak laki-laki maupun anak perempuan diajarkan tentang pembiasan -pembiasan yang baik sesuai dengan agama Islam dan budaya setempat,demikian juga dalam hal mendapatkan pendidikan formal, baik anak laki-laki maupun anak perempuan mendapatkan kesempatan yang sama,sehingga dalam hal pola asuh dalam pendidikan, terdapat kesetaraan gender pada keluarga Gayo.

Sikap suku Gayo dalam hal kesempatan memperoleh pendidikan pada anak, tidak menomorduakan perempuan, sehingga dalam hal pendidikan, secara umum anak perempuan di Gayo tidak berada dalam posisi subordinat terhadap laki-laki. Pernyataan ini didasarkan pada adanya kesempatan yang sama antara anak perempuan dan anak laki-laki dalam memperoleh pendidikan. Dengan demikian, secara kultural, keadaan masyarakat Gayo memang sarat dengan muatan patriarkis yang lebih mengutamakan laki-laki daripada perempuan. Namun dalam ranah pendidikan, hal ini tidak terjadi.

Dengan demikian, menurut penulis terdapat kesetaraan gender dalam pola asuh anak Perempuan pada keluarga Gayo dalam ranah pendidikan.

\section{Metode}

Dalam penelitian ini, metode penelitian yang digunakan adalah metode penelitian kualitatif deskriptif, dengan jenis sampling berupa sampling purposive. Jumlah sample yang digunakan dalam penelitian ini sebanyak 11 anggota kepala keluarga yang tinggal di wilayah Jakarta. Bogor, Depok, Tangerang dan Bekasi (Jabodetabek). Analisis data digunakan dengan Triangulasi, sedangkan validitas data dengan menggunakan snowbowling. 


\section{Hasil dan Pembahasan \\ Pola Asuh Orang Tua Gayo}

Keluarga merupakan lingkungan sosial pertama yang ditemui anak sebelum memasuki lingkungan sosial lainnya dan hubungan anak dengan orangtua dan anggota keluarga lainnya dapat dianggap sebagai suatu sistem yang saling berinteraksi. Sistem-sistem tersebut berpengaruh pada anak baik secara langsung maupun tidak langsung.

Banyak hal yang dapat dipelajari anak dalam keluarga, terutama yang berkaitan dengan orangtua dan setiap orangtua selalu menginginkan yang terbaik bagi anak-anak mereka. Perasaan ini kemudian mendorong orangtua untuk memiliki perilaku tertentu dalam mengasuh anak-anak mereka.

Perilaku orang tua dalam memberikan pola asuh anak dipengaruhi oleh berbagai faktor. Adawiyah menyatakan, bahwa faktor yang mempengaruhi pola asuh orang tua kepada anaknya adalah : tingkat sosial ekonomi keluarga, tingkat pendidikan orang tua, jarak tempat tinggal dengan sekolah, usia orang tua dan jumlah anak yang dimiliki (adawiyah, 2017).

Faktor - faktor lain yang dapat mempengaruhi pola asuh anak antara lain adalah bentuk sistem kekerabatan yang ada dalam masyarakat, budaya yang telah ada dan terjadi secara turun temurun dalam waktu yang cukup lama dan peran gender, seperti dinyatakan oleh Nauli, bahwa budaya memberikan pengaruh terhadap pola asuh orang tua.

\section{Sistem Kekerabatan dan Pola Asuh Keluarga.}

Keluarga adalah kelompok sosial yang terdiri dari kumpulan individu yang mempunyai hubungan pasti diantara para anggotanya, baik dalam hal aturan normatif, status, peran, ritual, dan lain-lain. Dalam keluarga juga dikenal adanya keluarga inti dan keluarga luas, dimana keluarga inti terdiri dari ayah, ibu dan anakanaknya. Sedangkan keluarga luas adalah kesatuan sosial atau kelompok yang terdiri dari semua orang, laki-laki dan perempuan karena ikatan keturunan atau perkawinan yang dihitung secara unilineal, yaitu menurut garis keturunan pihak bapak (laki-laki) saja atau pihak ibu (perempuan) saja atau keduanya (bilineal atau bilateral). Sebagai sebuah lembaga, keluarga merupakan lembaga pertama tempat anak mendapatkan pendidikan, sehingga keluarga dan sekolah dua hal yang tidak terpisahkan.

Dengan demikian keluarga merupakan lembaga primer atau lembaga pertama tempat anak memperoleh pendidikan. Pendidikan anak dimulai dalam keluarga, sehingga bagaimanapun orang tua terlibat dalam membentuk kepribadian dan kesuksesan anak dalam bidang karir dan akademik. Salah satu faktor yang menyebabkan sikap dan perilaku anak ditentukan oleh bagaimana keluarga memberikan pola asuh orang tua kepada anak.

Berdasarkan hal tersebut dapat disimpulkan, keluarga merupakan sekolah pertama bagi anak. Dalam lingkungan keluargalah anak pertama kali mendapatkan pola asuh yang kelak akan mempengaruhinya baik dalam perilaku, kepercayaan diri maupun kesuksesan dalam bidang karir dan akademik.

\section{Sistem Kekerabatan Masyarakat Gayo}

Kekerabatan merupakan hubungan kekeluargaan seseorang dengan orang lain yang mempunyai hubungan darah atau keturunan yang sama dalam satu keluarga. Dalam masyarakat Gayo bentuk sistem kekerabatannya adalah sistem kekerabatan patrilineal atau garis keturunan ditarik dari ayah atau nenek moyang laki-laki. 


\section{Sistem Partilineal dan Patriarki pada Masyarakat Gayo}

Gayo merupakan salah satu suku yang terdapat di wilayah Aceh dan menganut sistem kekerabatan patrilineal, yaitu adat masyarakat yang mengatur alur keturunan berasal dari pihak ayah. Patrilineal berasal dari dua kata bahasa Latin, yaitu pater yang berarti ayah, dan linea yang berarti garis. Jadi, patrilineal berarti mengikuti garis keturunan yang ditarik dari pihak ayah. Kata ini sering kali disamakan dengan patriarkat atau patriarki, meskipun pada dasarnya memiliki arti yang sedikit berbeda.

Sementara itu, patriarkat berasal dari dua kata bahasa Yunani, yaitu pater yang berarti "ayah", dan archein yang berarti memerintah. Jadi, patriarkat atau patriarki berarti kekuasaan berada di tangan ayah atau pihak laki-

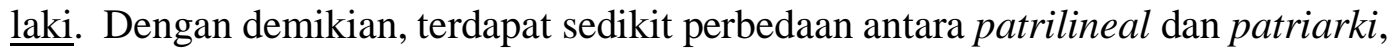
dimana patrilineal mengikuti garis keturunan ayah dan patriarki kekuasaan ada di tangan ayah. Namun pada umumnya pada sistem patrilineal juga berlaku faham patriarki.

Dalam penelitian ini yang dilihat sebagai keluarga adalah keluarga batih, yaitu keluarga yang terdiri dari ayah, ibu dan anak-anaknya, dimana kedua orang tua mereka berasal dari Gayo atau ibu mereka saja yang berasal dari Gayo. Hal ini disebabkan pada keluarga Gayo, pola asuh orang tua lebih menekankan pada pola asuh ibu kepada anak mereka dan bukan suatu yang mustahil, jika terjadi hal yang tidak baik pada anak, maka ibunyalah yang disalahkan, karena dalam masyarakat Gayo, ibulah penentu pertama dalam membentuk kepribadian dan kesuksesan anak. Ibu jugalah sekolah pertama bagi anak.

Dari penelitian yang telah dilakukan pada keluarga Gayo yang tinggal di wilayah kota Jakarta, Bogor, Depok, Tangerang dan Bekasi (Jabodetabek) diperoleh hasil bahwa Sistem kekerabatan masyarakat Gayo adalah sistem patrilineal atau menarik garis ayah. Dalam sistem patrilineal selain menarik garis keturunan dari ayah (laki-laki) juga memperlakukan ayah (laki-laki) sangat istimewa. Seperti dinyatakan oleh Hermaliza, patrilineal adalah suatu adat masyarakat yang mengatur alur keturunan yang berasal dari pihak ayah(Hermaliza, 2017).

Bagi suku Gayo, anak laki-laki peranannya sangat penting dalam sistem kekerabatannya, karena anak laki-laki sebagai penerus keturunan dan gelar kebangsawan di daerah Gayo. Oleh karena itu pada suku Gayo kedudukan dan peranan seorang wanita atau ibu yang tidak memiliki anak laki-laki akan terancam, atau mereka akan kehilangan kedudukan dan peranannya dalam rumah tangga dan keluarganya.

Berdasarkan uraian yang telah disampaikan, maka kesimpulan penulis adalah : sistem kekerabatan yang terdapat pada suku Gayo adalah sistem patrilineal dengan faham patriarki tentunya. Kedudukan laki-laki dan perempuan dibedakan berdasarkan jenis kelamin, dimana laki-laki mendapatkan perlakuan istimewa dan perempuan dinomorduakan (subordinasi).

Sistem tersebut berdampak pada pola asuh yang diberikan orang tua kepada anak-anak mereka, pola asuh yang diterapkan disesuaikan dengan budaya dan sistem kekerabatan yang ada dan telah dikonstruk oleh masyarakat.

\section{Peran Anak Perempuan Pada Keluarga Gayo}

Peran anak perempuan pada keluarga Gayo sangat besar, terutama dalam memberikan pelayanan pada keluarga. Semua aktivitas rumah tangga dilakukan oleh anak perempuan, anak perempuan banyak berperan baik pada ranah domestik maupun ranah public. Namun selama ini ada anggapan, bahwa pada keluarga 
patrilineal dan patriarcy, kebedaan perempuan berada pada posisi subordinasi, yaitu seperti dinyatakan oleh Wahjono (2011) Sub-ordinasi merupakan suatu keyakinan bahwa salah satu jenis kelamin dianggap lebih penting atau lebih utama dibandingkan jenis kelamin lainnya, sehingga ada jenis kelamin yang merasa dinomorduakan atau kurang didengarkan suaranya(Wahjono, 2011).

Pada ranah domestik anak perempuan mengerjakan seluruh pekerjaan rumah, mulai dari membersihkan rumah, memasak, mencuci dan mengerjakan pekerjaan rumah lainnya. Anak perempuan Gayo juga mengalami subordinat dibandingkan dengan anak laki-laki. Laki-laki memiliki posisi dominan dalam keluarga dan hal ini berdampak pada orang tua dalam mendidik anak dan pengambilan keputusan, adanya subordinasi ini disebabkan karena adat dan budaya yang sudah tertanam cukup lama.

Namun hal ini tidak terjadi dalam hal kesempatan memperoleh pendidikan baik pendidikan dalam keluarga maupun pendidikan formal. Dalam hal ini baik laki-laki maupun perempuan mendapatkan kesempatan yang sama. Adanya system patrilineal pada keluarga gayo tidak menyebabkan anak perempuan mendapatkan subordinat dalam hal mendapatkan pendidikan.

Hasil penelitian ini sesuai dengan hasil penelitian Tjandra dan Basaria (2018)yang menyatakan, ayah yang menjadi responden penelitian ini sudah menerapkan pola asuh yang sama antara anak perempuan dan anak laki-laki walaupun ayah berasal dari keluarga patrilineal. Sebanyak $84.6 \%$ dari total responden menerapkan pola asuh yang sama kepada anak perempuan dan anak lakilaki, dari jumlah ayah ini $92.9 \%$ ayah menerapkan pola asuh authoritative kepada anaknya, baik anak perempuan dan anak laki-laki (Tjandra \& Basaria, 2018).

Berdasarkan hal tersebut dapat dinyatakan bahwa pada keluarga Gayo terdapat kesetaraan gender dalam pola asuh terhadap anak perempuan dan secara psikologis keadaan ini menyebabkan timbulnya dampak positive terhadap kepribadian dan kesuksesan anak perempuan, terutama dalam hal karir.

\section{Pola Asuh Merupakan Warisan Budaya}

Bentuk pola asuh antara satu keluarga dengan keluarga lainnya berbeda, tergantung budaya masing-masing keluarga tersebut. Keshavarz dan Baharudin menyatakan, perilaku mengasuh anak dan pengaruhnya bervariasi tergantung pada budaya masing-masing daerah. Ini berarti bahwa cara anggota keluarga berinteraksi satu sama lain dipengaruhi oleh budaya masyarakat setempat dan setiap budaya mengembangkan pola yang pasti untuk membesarkan anak(Keshavarz \& Baharudin, 2009).

Demikian juga pola asuh orang tua Gayo. Dari hasil penelitian yang telah dilakukan, diperoleh hasil bahwa pada keluarga Gayo, pola asuh yang diterapkan berdasarkan budaya yang mereka anut, sehingga meskipun saat ini, bagi keluarga Gayo yang tinggal di wilayah Jakarta, Bodor, Depok, Tangerang dan Bekasi (Jabodetabek) sudah terdapat berbagai pembaharuan, seperti adanya era Gagdet ataupun adanya berbagai macam budaya lainnya selain Gayo, namun tetap saja para orang tua dalam mendidik anak masih berpegang pada budaya Gayo yang mereka miliki. Dengan demikian, pola asuh merupakan cara orang tua mendidik dan membimbing anak-anak mereka dan didasarkan pada pengalaman orang tua sebelumnya.

Keluarga terutama ibu merupakan lembaga pendidikan pertama bagi anak, dalam keluarga anak memperoleh bimbingan, arahan dan pembelajaran. Setiap orang tua menginginkan yang terbaik untuk anaknya. Untuk hal tersebut keluarga memberikan pola asuh agar anak tumbuh dan berkembang sesuai dengan yang 
diharapkan. Pola asuh orang tua terhadap anak dipengaruhi oleh banyak faktor dan salah satunya adalah faktor budaya.

Kebudayaan mempunyai hubungan yang sangat erat dengan masyarakat. Budaya antara lain mengandung nilai-nilai dan norma sosial, budaya juga diturunkan dari satu generasi ke generasi berikutnya. Shahzad dan kawan-kawan mendefinisikan budaya sebagai pengetahuan, penjelasan, nilai-nilai, kepercayaan, komunikasi, dan perilaku sekelompok besar orang, pada waktu dan tempat yang sama (Shahzad, 2012).

Hal ini juga terjadi dalam pola asuh orang tua pada keluarga Gayo. Dalam melakukan pola asuh orang tua Gayo banyak dipengaruhi baik oleh pola asuh yang dilakukan orang tua sebelumnya, maupun pengaruh budaya yang terdapat pada masyarakat tersebut.

\section{Bentuk Pola Asuh Orang Tua Gayo}

Adanya budaya yang terjadi secara turun temurun pada masyarakat Gayo berdampak pada adanya bentuk pola asuh khusus yang dimiliki oleh para perempuan Gayo. Dari hasil penelitian yang telah dilakukan, diperoleh hasil bahwa bentuk pola asuh yang diterapkan orang tua Gayo di wilayah Jabodetabek adalah bentuk pola asuh otorier. Hal ini terlihat dari sikap orang tua yang sudah mempunyai standar khusus tentang apa yang harus dilakukan anak, perilaku anak menuruti arahan orang tua.

Seperti dinyatakan oleh Mardliyah dan kawan-kawan, Pola asuh otoriter merupakan pola asuh dimana orang tua cenderung menetapkan standar yang mutlak harus dituruti, seperti halnya memaksa, memerintah, menghukum dan biasanya bersamaan dengan ancaman-ancaman. Orang tua mencoba untuk mengontrol perilaku dan sikap anak melalui perintah yang tidak boleh dibantah (Mardliyah et al., 2016).

Dari penelitian yang telah dilakukan, sebagian besar dari responden menyatakan bahwa orang tua mempunyai aturan tentang apa yang boleh dan tidak boleh dilakukan anak, orang tua juga menentukan batasan prilaku dan sikap anak sesuai dengan adat dan budaya Gayo. Orang tua memberikan arahan dan kontrol serta pertanggung jawaban anak jika anak melakukan perbuatan yang tidak sesuai dengan aturan yang telah ditetapkan oleh orang tua.

\section{Cara Orang Tua Mengembangkan Kecerdasan Spiritual Anak}

Pada keluarga Gayo, orang tua memberikan pendidikan melalui pola asuh dalam bentuk pendidikan dengan mengembangkan kecerdasan spiritual anak sejak anak memasuki masa prasekolah. Orang tua juga memberikan pendidikan moral dan pendidikan agama Islam pada anak.

\section{Pendidikan Anak Pra Sekolah Dalam Keluarga}

Pendidikan anak usia dini atau pendidikan pra sekolah merupakan suatu upaya pembinaan yang ditujukan kepada anak sejak lahir sampai dengan anak berusia enam tahun yang dilakukan melalui pemberian rangsangan pendidikan untuk membantu pertumbuhan dan perkembangan jasmani dan rohani agar anak memiliki kesiapan dalam memasuki pendidikan lebih lanjut.

Pada keluarga Gayo dengan sistem patriarki tidak berdampak pada perbedaan pola asuh dalam pembekalan pendidikan anak. Permainan pok nane yang merupakan salah satu bentuk permainan yang dilakukan bersama anak balita dimana pada saat bermain tersebut, anak diajak bertepuk tangan disertai dengan melantunkan kalimat-kalimat thayibah dilakukan baik pada anak laki-laki maupun anak perempuan, sehingga tidak terjadi subordinasi anak perempuan dari anak laki-laki. 
Dengan demikian, seperti telah dinyatakan terdahulu, sistem patrilineal pada keluarga Gayo, tidak berdampak pada subordinasi anak perempuan dalam hal mendapatkan pendidikan. Hal ini tidak tidak sesuai dengan pernyataan Sultana yang menyatakan bahwa sistem patriarki memberikan dampak terhadap ketidak setaraan gender dalam pendidikan, hal ini terjadi disebabkan orang tua lebih memberikan prioritas pendidikan pada anak laki-laki dibandingkan dengan anak perempuan Bahkan menurut Chowdhury (Chowdhury, 2015), penerapan sistem patriarki menyebabkan terjadinya kekerasan pada perempuan di Bangladeh.

Banyak hal yang dilakukan orang tua Gayo dalam memberikan pendidikan kepada anak mereka, baik laki-laki maupun perempuan dalam bentuk pola asuh dan hal ini telah dilakukan sejak anak masih dalam buayan sampai mereka dewasa. Hal yang paling utama yang menjadi fokus mereka adalah dalam hal pembentukan moral anak. Anak-anak mereka, baik laki-laki maupun perempuan telah dibekali dengan pendidikan moral sejak anak masih usia dini.

\section{Pendidikan Moral Anak}

Nauli menyatakan, Efek pengasuhan yang diberikan oleh ibu selaku orangtua berpengaruh terhadap aspek-aspek moralitas dalam diri anak. Berbagai macam karakteristik moralitas yang akan diinternalisasi dalam diri anak antara lain adalah seperti orientasi sosial, pengendalian diri, kepatuhan, harga diri, empati, hati nurani, penalaran moral, dan altruisme(Nauli et al., 2019).

Pada keluarga Gayo memberikan pendidikan moral pada anak merupakan hal utama yang harus dilakukan, sehingga dalam pola asuh anak, masalah moral utama merupakan hal yang selalu dilakukan, anak diajarkan bagaimana cara berbicara dan bersikap sopan baik kepada orang yang lebih tua atau dengan teman sebaya. Pendidikan moral anak sejak usia dini dilakukan melalui pendidikan pembiasaan.

Pola asuh orang tua berupa pendidikan, bimbingan, kasih sayang dan kontrol yang diberikan orang tua kepada anak sejak dini dapat berdampak terhadap pembentukan pembiasaan. Adanya pengulangan, konsistensi dan orang tua sebagai tutor dapat menjadi stimulus yang berperan dalam membentuk kebiasaan anak, kebiasaan inilah yang pada akhirnya membentuk perilaku dan moral anak. Keadaan ini dapat digambarkan seperti pada gambar 1 .

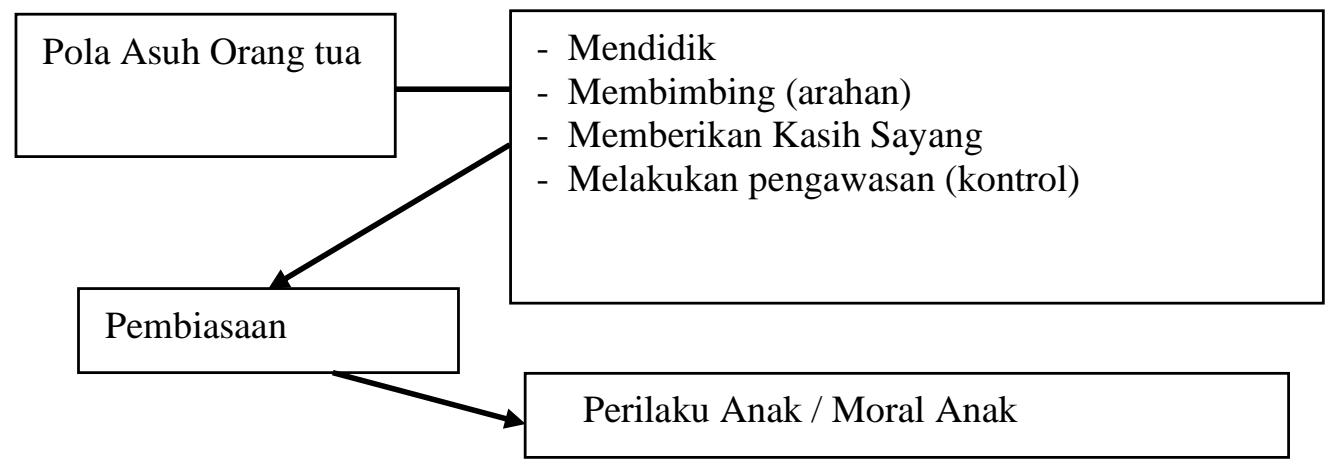

Gambar 1. Pembentukan Moral Melalui Pola Asuh Orang Tua

Dari gambar 1 terlihat bahwa pola asuh orang tua berupa: pendidikan, bimbingan (arahan), kasih sayang dan kontrol dapat membentuk moral anak melalui pembiasaan. Pembiasaan merupakan salah satu metode dalam pendidikan yang dianggap efektif dalam membentuk perilaku anak/siswa, karena ketika suatu 
perilaku sudah terbiasa dilakukan melalui pembiasaan, maka akan menjadi kebiasaan (habit) bagi yang melakukannya, kemudian akan berubah menjadi sebuah tradisi yang sulit ditinggalkan. Ulwan menyatakan, metode pendidikan pada anak terutama dalam memperbaiki anak, yang paling berperan penting adalah dengan metode pengajaran dan pembiasaan (Ulwan,2013).

Nata menyatakan Pembiasaan merupakan salah satu metode pendidikan yang sangat penting, terutama bagi anak-anak. Mereka belum mengetahui baik dan buruk, kewajiban-kewajiban yang harus dilakukan serta mereka juga belum mengatahui hal-hal yang harus ditinggalkan, sehingga mereka perlu dibiasakan dengan tingkah laku, keterampilan, kecakapan, dan pola pikir tertentu. Anak perlu dibiasakan pada sesuatu yang baik, yang kemudian akan mengubahnya menjadi kebiasaan baik (Nata, 2013).

Dengan demikian, begitu pentingnya pembiasaan dalam proses pendidikan, terutama dalam pendidikan moral, dikarenakan dengan pembiasaan akan terjadi proses internalisasi nilai-nilai moral bagi anak. Tujuan dari proses internalisasi nilai moral ini bertujuan agar anak dapat mengamalkan nilai-nilai moral yang ditanamkannya sejak dini.

Pendidikan melalui pembiasaan sesuai dengan teori pendidikan behaviorist dari Ivan Pavlov yang menyatakan bahwa belajar adalah proses pembiasaan melalui pemberian stimulus, karena setiap stimulus akan merangsang aktivitas otak. Teori pendidikan klasik ini berlandaskan pada filsafat klasik, yang memandang bahwa pendidikan berfungsi sebagai upaya memelihara, mengawetkan dan meneruskan warisan budaya.

Pendidikan melalui pembiasaan juga sesuai dengan teori yang dinyatakan oleh Aristoteles, yang menyatakan, untuk keberhasilan pendidikan terutama pada pembentukan moral, maka perlu adanya pengulangan terhadap hal-hal baik, konsistensi dan tutor yang baik.

Pernyataan ini menunjukkan perlunya stimulus dalam pembelajaran dengan habituasi. Dalam penelitian ini yang berperan sebagai stimulus adalah pola asuh orang tua. Pembiasaan bisa terjadi karena adanya stimulus atau rangsangan. Dalam hal ini pola asuh berfungsi sebagai stimulus yang dapat merangsang terjadinya pembiasaan pada anak.

Schmid dan kawan-kawan menyatakan, mekanisme pembentukan dan penyimpanan menurut pembelajaran habituasi adalah sebagai berikut: Habituasi menggambarkan penurunan progresif amplitudo atau frekuensi respons motorik terhadap stimulasi, sensorik berulang yang tidak disebabkan oleh adaptasi reseptor sensorik atau kelelahan motoric (Schmid et al., 2015).

Selanjutnya pendidikan melalui pembiasaan juga sesuai dengan pernyataan John Lock yang menyatakan ketika anak dilahirkan dalam keadaannya tidak mengetahui apa-apa. Teori ini kemudian dikenal dengan teori Tabula Rasa.

Dari pemaparan yang telah disampaikan, teori pembiasaan mendukung teori behaviorist yang menyatakan untuk melakukan pembelajaran, perlu adanya stimulus, yang dapat merangsang anak agar bersikap baik, sehingga terbentuk moral yang baik. Ketika anak dilahirkan, dalam keadaan tidak mengetahui apa-apa, hal ini sesuai dengan QS An -Nahl ayat 78. 


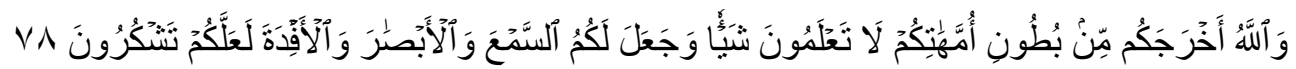

78. Dan Allah mengeluarkan kamu dari perut ibumu dalam keadaan tidak mengetahui sesuatupun, dan Dia memberi kamu pendengaran, penglihatan dan hati, agar kamu bersyukur.

keluargalah sebagai institusi pertama tempat anak melakukan interaksi, sehingga Islam memandang keluarga sebagai lingkungan pertama di mana anak berinteraksi. Islam juga memandang kedua orang tualah sebagai penanggung jawab terpeliharanya fitrah seorang anak (Shihab, 2007). Dengan demikian sudah menjadi kewajiban orang tua melalui pola asuh yang diberikannya kepada anak, untuk membimbing dan mendidik agar anak agar mempunyai akhlak yang baik. Pola asuh dalam keluarga memberikan dampak terhadap pembiasaan anak. Melalui proses pengulangan, konsistensi dan arahan dari orang tua, maka terbentuk pembiasaan pada anak. Pembiasaan yang baik, akan memberikan hasil yang baik, demikian juga sebaliknya.

Pola asuh orang tua bertujuan membentuk anak memiliki akhlak mulia, oleh karena itu pola asuh sangat berperan dalam membentuk masyarakat berkepribadian baik. Pola asuh merupakan kegiatan yang kompleks yang mencakup banyak perilaku spesifik yang dapat mempengaruhi outcome anak. seperti dinyatakan oleh Bibi dan kawan-kawan bahwa pola asuh merupakan faktor signifikans dalam perkembangan psikososial anak dan remaja(Farzana Bibi, 2013).

Dengan demikian, pola asuh merupakan faktor penentu sikap, perilaku dan kesuksesan anak. Pola asuh juga merupakan pendidikan yang berkaitan dengan moral anak, karena anak mendapatkan pola asuh dari keluarga yang merupakan lembaga pertama yang ditemui anak sebelum lembaga sosial lainnya.

Berdasarkan uraian tersebut dapat disimpulkan, bahwa pola asuh memberikan dampak terhadap perkembangan anak, baik secara psikis, moral maupun kesuksesan. Pola asuh yang tepat akan memberikan dampak positif terhadap anak, demikian juga sebaliknya.

Pendidikan dalam rangka membentuk moral yang baik memang seharusnya diberikan sejak anak usia dini, hal ini diharapkan ketika anak memasuki masa remaja dan selanjutnya menjadi dewasa, anak telah memiliki pembiasaan baik. Pendidikan yang dilakukan melalui pembiasaan sulit untuk dilakukan perubahan.

\section{Pendidikan Moral Anak Sejak Usia Dini.}

Pola asuh yang diberikan orang tua pada anak bertujuan menanamkan nilainilai budaya dan moral yang telah ada, agar anak tumbuh menjadi manusia yang diharapkan orang tua, masyarakat serta nusa dan bangsa. Sama seperti halnya para orang tua pada umumnya, pola asuh dan bimbingan orang tua Gayo terhadap anaknya sudah dimulai sejak anak masih bayi. Harapan orang tua agar anak tumbuh sesuai dengan harapannya telah sering diperdengarkan ketika anak masih dalam buayan.

Orang tua menimang anak mereka dengan mengucapkan kalimat-kalimat keagamaan serta harapan-harapan baik yang diinginkan orang tua. Hal ini menunjukkan betapa para orang tua Gayo telah menanamkan nilai-nilai keagamaan dan budaya serta moral sejak anak masih dalam buayan. 
Setelah memasuki balita, anak juga diajak bermain, baik oleh orang tua maupun para keluarga lainnya dengan permainan Pok Ane (Pok Nane). Pok Ane (Pok Nane) adalah tradisi di Gayo untuk mengajak anak-anak bermain, dengan bertepuk tangan dan menyanyikan kalimat-kalimat yang baik.

Pok Ane merupakan nyanyian yang dinyanyikan untuk mengajak si kecil (anak-anak) bermain sambil bertepuk tangan. Biasanya nyanyian tersebut mengajak si kecil untuk menepuk-nepukkan tangan atau kakinya satu sama lain sesuai lirik lagu. Isi dari nyanyian tersebut berisi doa dan harapan serta anjuran kebaikan kepada anak.

Pendidikan terhadap anak terus berlanjut ketika anak memasuki masa kanak-kanak bahkan remaja. Pola asuh yang diterapkan orang tua Gayo dilakukan melalui pembiasaan-pembisaan baik pada anak. Para orang tua Gayo, memberikan pola asuh disesuaikan dengan adat dan budaya Gayo.

Pendidikan melalui pembiasaan dapat dilakukan dengan cara melakukan pengulangan dan konsistensi melalui arahan tutor yang menetapkan suatu target tertentu. Hal ini juga yang dilakukan para orang tua Gayo. Mereka memberikan pola asuh melalui pendidikan, bimbingan (arahan), kasih sayang dan kontrol secara berulang-ulang. Hal ini dimaksudkan agar anak dapat terbiasa melakukan perbuatan baik.

\section{Kesetaraan dan Keadilan Gender Dalam Perspektif Islam.}

Wahjono mendefinisikan bahwa Gender mempunyai arti, perbedaan lelaki dan perempuan yang tidak bersifat kodrati. Perbedaan yang bukan kodrati itu misalnya: perbedaan peran, tanggung jawab, fungsi dan bahkan ruang tempat dimana manusia beraktivitas(Wahjono, 2011). Kesetaraan dan keadilan gender merupakan dua hal yang sering hadir secara berdampingan, namun keduanya mempunyai makna yang berbeda.

Dalam perspektif Islam, tidak ada pembedaan antara laki- laki dan perempuan dalam hal gender, mereka semua sama di hadapan Allah, oleh karena itu, laki-laki dan perempuan memiliki hak dan derajat yang sama. Hal ini berarti, adanya keadilan dan kesetaraan gender tidak bertentangan dengan ketentuan dalam Islam.

Islam memandang laki-laki dan perempuan memiliki kesetaraan baik pada saat penciptaan manusia, yaitu: sebagai hamba Allah, Sebagai Khalifah Allah di bumi, maupun dalam hal meraih prestasi maksimal, sehingga dalam Islam tidak mengenal adanya diskriminasi gender.

Dari uraian tersebut dapat disimpulkan, dalam Islam tidak mengenal adanya ketidakadilan dan ketidaksetaraan gender. Karena keadilan gender berarti memberikan perlakuan sesuai dengan keadaannya dan kesetaraan gender berarti memberikan kesempatan kepada perempuan untuk meraih prestasi sesuai dengan kemampuannya dan bukan berdasarkan jenis kelaminnya.

\section{Kesimpulan}

Keluarga Gayo merupakan keluarga yang menganut system kekerabatan patrilineal atau mengambil keturunan dari garis ayah, sehingga mereka juga menganut system patriarki atau dominasi terdapat pada laki-laki. Dalam hal pendidikan, terjadi kesetaraan gender antara laki-laki dan perempuan, sehingga mereka memiliki kesempatan yang sama dalam hal memperoleh pendidikan dalam keluarga. 


\section{Daftar Pustaka}

Adawiyah, R. (2017). Pola Asuh Orang Tua dan Implikasinya Terhadap Pendidikan Anak. Jurnal Pendidikan Kewarganegaraan.

Chowdhury, E. H. (2015). Rethinking patriarchy, culture and masculinity: Transnational narratives of gender violence and human rights advocacy. Journal of International Women's Studies.

Duschinsky, R. (2012). Tabula rasa and human nature. Philosophy. https://doi.org/10.1017/S0031819112000393

Farzana Bibi, F. B. (2013). Contribution of Parenting Style in life domain of Children. IOSR Journal of Humanities and Social Science. https://doi.org/10.9790/0837-1229195

Hermaliza, E. (2017). Sistem Kekerabatan Suku Bangsa Kluet Di Aceh Selatan the Kinship System of Kluet Etnics in South Aceh. Widyariset.

Keshavarz, S., \& Baharudin, R. (2009). Parenting style in a collectivist culture of Malaysia. European Journal of Social Sciences.

Kuppens, S., \& Ceulemans, E. (2019). Parenting Styles: A Closer Look at a WellKnown Concept. Journal of Child and Family Studies. https://doi.org/10.1007/s10826-018-1242-x

Mardliyah, U., Yugistyowati, A., \& Aprilia, V. (2016). Pola Asuh Orang Tua Sebagai Faktor Penentu Kualitas Pemenuhan Kebutuhan Dasar Personal Hygiene Anak Usia 6-12 Tahun. Jurnal Ners Dan Kebidanan Indonesia. https://doi.org/10.21927/jnki.2014.2(2).86-92

Merlina, N. (2010). Pola Pengasuhan Anak Pada Komunitas Adat Giri Jaya (Suatu Tinjauan Sosial Budaya). Patanjala: Jurnal Penelitian Sejarah Dan Budaya. https://doi.org/10.30959/patanjala.v2i2.217

Nauli, V. A., Karnadi, K., \& Meilani, S. M. (2019). Peran Ibu Pedagang Pasar 24 Jam Terhadap Perkembangan Moral Anak (Penelitian Studi Kasus di Kota Bekasi). Jurnal Obsesi: Jurnal Pendidikan Anak Usia Dini. https://doi.org/10.31004/obsesi.v3i1.179

Rani, B. S. (2014). Impact of Parenting Styles on Career Choices of Adolescents. Journal Of Education and Social Policy.

Schmid, S., Wilson, D. A., \& Rankin, C. H. (2015). Habituation mechanisms and their importance for cognitive function. In Frontiers in Integrative Neuroscience. https://doi.org/10.3389/fnint.2014.00097

Shahzad, F. (2012). Impact of Organizational Culture on Organizational Performance: An Overview. Interdisciplinary Journal of Contemporary Research in Business.

Sharma, R. (2013). The family and family structure classification redefined for the current times. Journal of Family Medicine and Primary Care. https://doi.org/10.4103/2249-4863.123774

Tjandra, K. P., \& Basaria, D. (2018). Pola Asuh Ayah Terhadap Anak Perempuan Dan Anak Laki-Laki Keluarga Patrilineal. Jurnal Muara Ilmu Sosial,

Dan

Seni. https://doi.org/10.24912/jmishumsen.v2i1.1749 
Kesetaraan Gender dalam Pola Asuh Anak.. I

Wahjono, S. I. (2011). Gender Problem in Family Business. Balance Economics, Business, Management and Accounting Journal. 